\title{
Federalism and regional interest intermediation in Brazilian public policies ${ }^{1}$
}

\author{
CELINA SOUZA* \\ Federal University of Bahia, Brazil
}

\begin{abstract}
SUMMARY
Brazil became a highly decentralized country following democratization and the 1988 Constitution. The consequences of decentralization at the federal level are quite clear: the federal government is facing financial constraints and difficulties in building governing coalitions, allowing the Presidents to govern and to implement public policies, especially those concerning fiscal control. At the level of the states, however, the results of decentralization are quite heterogeneous given the country's high degree of regional inequality. The article identifies the cleavages and tensions surrounding federal-state relations, as well as the mutual dependency of the states and the federal government. It argues that the Brazilian experience of political and financial decentralization has contributed to the prospects of democratic consolidation and has forced the federal government to negotiate and compromise with subnational governments the implementation of national policies. On the other hand, the Brazilian experience highlights the constraints of decentralization in countries with deeprooted regional disparities. Furthermore, the financial weakness of the federal government which has been brought about by decentralization and by fiscal control brings new tensions to the federal arrangements and to public policies. Copyright (C) 1999 John Wiley \& Sons, Ltd.
\end{abstract}

\section{INTRODUCTION}

With the promulgation of the 1988 Constitution, Brazil became a very decentralized country in the distribution of political and financial resources, thus affecting public policies (Souza, 1992, 1994, 1997a). The 1988 Constitution was the result of the country's commitment to democratic values, in which political, financial and administrative decentralization fulfilled an important role. Nevertheless, after the promulgation of the constitution, the role of the State, especially that of the federal government, as a provider of social and economic policies as well as in its responsibility for evening out inequalities among Brazilian states and regions has had to face many challenges, while the so-called market mechanisms have been gaining salience. Furthermore, economic reforms, especially those designed to control inflation, have been reducing support from the federal government to the states for the provision of infrastructure and local and regional public services.

*Correspondence to: Celina Souza, Department of Finance and Public Policies, Federal University of Bahia, Rua Quintino de Carvalho 153/702, 40155-280 Salvador Bahia, Brazil. Email: celina@ufba.br

${ }^{1}$ This article was first presented as a paper at the international seminar 'Restructuring and Government Reform: Brazil and Latin America in a Globalizing Context' held in São Paulo, Brazil, 18-21 May 1998.

CCC 0271-2075/99/030263-17\$17.50

Copyright (C) 1999 John Wiley \& Sons, Ltd. 
At the federal level, the results of decentralization are quite clear: the federal government is particularly affected by financial constraints and is finding it difficult to build governing coalitions, although it has been finding ways to overcome those difficulties. At the subnational level, however, the results of decentralization present a high level of heterogeneity given the country's regional disparities.

Brazil has been marked, from the beginning of its republican history, by the existence of deep-rooted regional inequalities within the federation. The latest report by the United Nations Development Program and a federal government think-tank, the IPEA, brought to the fore the existence of three 'Brazils', composed of (a) an area constituting seven states in the south of the country which, together with the Federal District, share a high level of human development; (b) an area which follows the north-western direction, starting in Minas Gerais, and which has a medium level of human development; and (c) an area composed of the states of the North-East plus the states of Pará and Acre, which is characterized by low levels of human development (IPEA and PNUD, 1996). ${ }^{2}$ These results depict a new map of Brazilian regions, somewhat different from the traditional geographic map which divides Brazil into five regions.

This article examines the impact of decentralization upon federalism and the formulation and implementation of policies in Brazil, in particular in the relationship between the federal government and the states. These issues are discussed focusing on Brazil's regional inequalities given the fact that these inequalities have caused new tensions to the federal equilibrium which was achieved by the 1988 Constitution and agreed during the transition to democracy.

The article argues that the Brazilian experience of political and financial decentralization favours the prospects of democratic consolidation in Brazil and has made Brazil more 'federal' through the emergence of new political actors in the political scene and the existence of several power centres competing among themselves. The state governors, especially those governing economically powerful states, and the mayors of the state capitals became one of the main centres of power, compelling the federal government to negotiate with the subnational spheres the addressing of national public policies. In this sense Brazil became not only more democratic but also more 'federal'. On the other hand, the Brazilian experience shows that decentralization might reduce the evening out of the country's regional inequalities because of the financial and political weakening of the federal government. This picture brings new challenges and tensions for addressing solutions to old problems, such as those of regional inequalities.

Since the promulgation of the 1988 Constitution, literature on Brazilian federalism has pursued new approaches in order to incorporate the high degree of decentralization promoted by the constitution. Initially, the literature on decentralization and federalism tended towards the adoption of two approaches, as shown by Abrucio et al. (1993). On the one hand, there were studies which criticized current financial decentralization and called for the return of the financial strength of the federal government. On the other hand, there were studies which saw decentralization as an

\footnotetext{
${ }^{2}$ The states of Rio Grande do Sul, São Paulo, Santa Catarina, Rio de Janeiro, Paraná, Mato Grosso do Sul and Espírito Santo, plus the Federal District, belong to the first category. In the second category are the states of Minas Gerais, Goiás, Mato Grosso, Rondônia, Amazonas, Roraima and Amapá. In the third group are the states of Pará, Acre, Sergipe, Bahia, Pernambuco, Rio Grande do Norte, Maranhão, Ceará, Piauí, Alagoas and Paraíba.
} 
improvement against the Brazilian tradition of centralization and authoritarianism. Subsequently, these simplified visions of decentralization and federalism started to be replaced by studies attempting to incorporate analyses related to fiscal, regional, social, economic and political issues. More recently, professional and academic studies in the area of decentralization and federalism have increased in number and have taken three main directions. The first of these involves studies which attempt to build a conceptual basis about decentralization moving forward the traditional legal and/or administrative approaches. Fiori (1995) and Souza (1997a) follow this direction. The second has an empirical approach and aims at analysing the effects of decentralization upon the federal government and the subnational spheres. Research projects carried out by NEPP/UNICAMP (Center for the Studies of Public Policies/Campinas University), IPEA (Institute of Applied Economic Research) and FUNDAP (Center for Administrative Development) are among the most well known. The latter organization co-ordinated a project covering several national and international aspects of decentralization and federalism (Affonso and Silva, 1995a,b,c, 1996a,b). The third direction, frequently incorporating aspects of the other two, shows the unequal effects of decentralization. Studies by Bremaeker, ${ }^{3}$ IPEA/IBAM (1994), Afonso and Lobo (1996), Melo (1996) and Souza (1996a,b) follow this path. A common feature among the approaches described is the treatment of decentralization as part of the discussion on federalism. Some of these studies also widen the approach of decentralization to incorporate it with democratic consolidation, State reform and globalization.

This article first presents a brief review of the literature, in particular Anglo-Saxon literature, on federalism; it then provides an overview of the main economic and social features of the Brazilian states and regions, showing the degree of regional inequality. Following this, the ways in which the states have been using their political strength to negotiate their financial constraints and how these negotiations influence the federation and public policies are discussed.

\section{FEDERALISM: A BRIEF THEORETICAL REVIEW ${ }^{4}$}

In federal countries it is of crucial importance to discuss the issue of public policies taking into consideration the analytical frameworks involving federalism and decentralization. Federal political systems are based on political and social theories of federalism. The existence of a federal system implies some degree of co-operation between the federal government and the governments of the member units. This is why the degree of decentralization between governmental units is of crucial importance for a better understanding of how a federal system works in practice. Hence political science and public administration literatures have become interested not only in theories of federalism and their application to constitutions and legislation, but also with how federal systems actually operate.

\footnotetext{
${ }^{3}$ François Braemaeker, 'Mitos e verdades sobre as finanças dos municípios brasileiros', IBAM, Rio de Janeiro, 1994, unpublished.

${ }^{4}$ An earlier version of this section appeared in Souza (1996a).
} 
Despite the fact that federalism occasionally comes hand in hand with decentralization, that is to say, with substantial autonomy for the member states, decentralization is not necessarily a prerequisite for federalism, as discussed by Lijphart (1984).

In its broadest sense the word federalism refers to the linking of people and institutions by mutual consent for a specific purpose, without the sacrifice of their individual identities (Harman, 1992, p. 337). The concept of federalism has been discussed at length in the literature. There is also a much-disputed debate on its essential characteristics. ${ }^{5}$ In this territory of conceptual disputes, this work has opted to follow Burgess's (1993a, p. 8) view, in which federalism is treated as a value concept, the recommendation and the promotion of support for federation. Therefore the logic of federations is federalism, which is the ideological perception of what follows from federalizing. More than a semantic difference, the need to distinguish federation and federalism is important given (a) the variety in the practice of federal principles within each federation and (b) the emergence of forms of federalism in countries and in institutions which are not a federation, Belgium and the European Community being the most cited examples. This article has opted for the view of federalism as a political ideology, as developed by Burgess (1993b) filling a gap in the federalism literature, more concerned with the practicalities of territorial and governmental arrangements. Burgess (1993b, p. 104) defined political ideology as 'values, attitudes, beliefs and interests which combine to furnish action with purpose and commitment'. This definition does not imply the inclusion of moral principles such as freedom and democracy, but rather that values reflect interests. Therefore the advocacy of federalism is the pursuit of self-interest. The importance of introducing the notion of federalism as political ideology lies in the fact that change and development remain the most difficult aspects to explain and understand in the study of federal political systems, but the notion of federalism as political ideology can provide a useful route into this complicated area.

Burgess's contribution opened the way for an investigation of the motivations behind the promotion of each federalism, given that they vary enormously. Each federalism, not only each federation, incorporates a range of attributes which intermingle to produce complex patterns of interests and identities. Therefore each federalism is driven by a leitmotif, although this leitmotif may express itself in different ways within a federation according to a particular set of interests in a given historical time. The North American federalism was, and continues to be, dominated by the pursuit of 'checks-and-balances' mechanisms. In Canada, India, Pakistan, Malaysia, Nigeria, Central Africa and Switzerland the leitmotif has been the preservation of linguistic, racial and religious minorities (Gagnon, 1993). In Germany the driving force has been to build and to consolidate institutions able to respond to the defeat of the first German democracy in 1933 and to Nazi dictatorship (Sontheimer, 1988). The leitmotif of Australian federalism has been credited as being the commercial advantages of a common market (Else-Mitchell, 1983) and/or to a federalism in which the strength of state centres of power tends to check centralizing forces (Rydon, 1993). The leitmotif of Argentinean federalism was, and continues to be, the struggle of the provinces against the power of Buenos Aires (Schapira, 1992).

\footnotetext{
${ }^{5}$ Stewart (1984) mentions the existence of 497 representations of federalism, both literal and figurative. In the domain of political science, the most well-known studies are those based on the US experience, mainly by Elazar (1984) and Duchacek (1987).
} 
This article argues that the driving force of Brazilian federalism has always been the need to accommodate the demands of conflicting elites and to cope with great regional inequalities.

\section{BRAZILIAN REGIONS AND STATES: SOME FEATURES}

Brazil is a country marked by inter- and intra-regional disparities. Despite a certain degree of spatial deconcentration which occurred in the mid-1970s, the gap between states and regions remains wide. From the geographical viewpoint, Brazil is divided into five regions. The state of São Paulo, in the South-East, is the centre of the Brazilian economy. In 1985 the South-East concentrated 70\% of the country's industrial production and 58\% of its GDP, 34\% being in São Paulo. In 1970, São Paulo's participation in the GDP reached 39\%. Despite a certain degree of economic deconcentration after 1975, the gap between São Paulo and the South-East vis-à-vis the other states and regions remains wide.

In 1991 the South-East, which accounts for $10.8 \%$ of the country's territory and $42.6 \%$ of the population, concentrated $59 \%$ of GDP and $66 \%$ of the industrial production. The North-East, in contrast, where $28.9 \%$ of the population live, contributed to $13.6 \%$ of GDP and $12 \%$ of the industrial production. ${ }^{6}$

Income per person in the South-East is almost three times greater than that in the North-East. Marked differences may also be found in all other indicators. Work by IPEA (1993) shows that in 1990 out of 32 million Brazilians whose income was only enough for a daily diet, according to the guideline established by the Food and Agricultural Organization, $54.5 \%$ of them live in the North-East, $2.2 \%$ in the North, $25.2 \%$ in the South-East, $12.9 \%$ in the South and $5.2 \%$ in the Centre-West. Life expectation in the North-East was 58.8 years in 1990, whereas the country's average was 64.9. Income per capita in the North-East was US\$918 in contrast with the country's average of US\$2241 (Albuquerque, 1993).

As regards the states, the participation of the main state economies in Brazil's GDP was, in 1990, as follows: São Paulo, with 35\%; Rio de Janeiro, $11 \%$; Minas Gerais, 9.5\%; Rio Grande do Sul, 7.8\%; Paraná, 7.7\%; and Bahia, 5\%. However, GDP per capita shows a different distribution among the states. The highest rate was found in Brasília (US\$4988), followed by São Paulo, with US\$3993; Rio de Janeiro, with US\$3352; Rio Grande do Sul, with US\$2738; Santa Catarina, with US\$2344; and Paraná, with US\$2037. Minas Gerais goes down to seventh place, with US\$1850, and Bahia falls to tenth place, with US\$1226 (Albuquerque, 1993).

These socio-economic disparities also have a political pay-off: smaller and economically weaker states hold proportionally more seats in the Chamber of Deputies than bigger constituencies. The most significant difference is between the North and the South-East. The latter, with $46 \%$ of the electorate, holds $33.6 \%$ of the seats in Congress, while the North, with $4.8 \%$ of the electorate, holds $11.3 \%$. This over-representation was first introduced in 1932 to counterbalance the power of the states of São Paulo and Minas Gerais in the federation. It has been maintained ever since. However, there are historical and political facts favouring this overrepresentation. The scheme was set up as a way to decrease the control of São Paulo

\footnotetext{
${ }^{6}$ Data from Guimarães Neto (1995).
} 
and Minas Gerais over the whole country. Another reason may be added: the overrepresentation of weaker economic units of the federation forces the political system, the federal government and Congress to incorporate the problems of Brazil's regional inequalities into the political agenda.

Another way to counterbalance the country's regional inequality has been the adoption, since 1946, of a fiscal system aiming at a better vertical and horizontal balance through the distribution of the national revenue from the well-off to the worst-off regions. This scheme was considerably extended by the 1988 Constitution. As reported by Afonso and Lobo (1996), the center-south of the country generates around $80 \%$ of GDP and of the national revenue but remains only $60 \%$ of the expenditure. Because of the system of horizontal balance, which transfers resources from better-off states to worst-off ones, the fiscal system is highly entangled, and whenever the economy of well-off states slows down, less developed regions are also affected. On the other hand, of all fiscal incentives, $38.3 \%$ go to the Amazon region, $9.6 \%$ to the North-East and $51.6 \%$ to the Center-West, South and South-East regions (Camargo, 1993).

Brazilian federalism and the relationship between the federal and the state governments are no different from the country's socio-economic features: they are marked by enormous differences and complexity. The federation presents a high participation of the subnational spheres in the national revenue, as well as in expenditure, without great interference from the central government. On the other hand, the country pays a relatively high price to maintain national unity. It has a complex system of federalism, coupled with an inarticulate system of intergovernmental relations, and formulation and implementation of public policies.

\section{THE IMPACT OF DECENTRALIZATION UPON FEDERALISM AND THE FEDERAL GOVERNMENT ${ }^{7}$}

The Brazilian fiscal system has experienced many changes in the last decades, all related to the achievement of economic or political goals. After the fiscal reform of 1966, where centralization was the result, the military regime started to adopt more flexible measures, especially that of increasing local revenue, but the most far-reaching change occurred with the 1988 Constitution, which has deeply changed the federation, mainly in its political and fiscal features.

In fact, decentralization is the dominant characteristic of the system adopted in 1988 not only for tax assignments and intergovernmental transfers, but also in the case of expenditure. The constitution placed the Brazilian subnational governments close to the average of most industrialized federal countries, as Table 1 shows. $^{8}$

Among developing countries, Brazil has the most decentralized fiscal system. In Mexico, $80 \%$ of public expenditure is controlled by the central government (Shah,

\footnotetext{
${ }^{7}$ Earlier versions of this and subsequent sections appeared in Souza (1997b,c).

${ }^{8}$ Brazilian subnational governments enjoy great freedom in the allocation of revenues transferred from the federal government, the need to apply $25 \%$ of the revenue in education being the only constitutional restriction. This feature distinguishes Brazil from other federal countries, such as the USA, where there has been a federal government trend to transfer responsibilities without the necessary resources. This situation has brought about pressures from North American states and municipalities on the federal government against what became known as unfunded mandates.
} 
Table 1. Total expenditure by level of government in some federal countries.

\begin{tabular}{lcccc}
\hline & & \multicolumn{3}{c}{ Level of government } \\
\cline { 3 - 5 } Country & Ending year & Central & State & Local \\
\hline Australia & 1987 & 52.8 & 40.4 & 6.8 \\
Austria & 1987 & 70.4 & 12.7 & 16.9 \\
Canada & 1987 & 41.3 & 40.3 & 18.4 \\
Germany & 1983 & 58.7 & 21.5 & 19.8 \\
United States & 1987 & 60.3 & 17.3 & 22.4 \\
Switzerland & 1984 & 47.5 & 28.3 & 24.2 \\
Brazil & 1987 & 65.8 & 24.5 & 9.7 \\
& 1992 & 56.0 & 28.0 & 16.0 \\
\hline
\end{tabular}

Sources. Levin (1991, p. 12) and ABRASF (1992, p. 9).

1991, pp. 24-26). In India and Indonesia the federal government dominates the federation, undertaking $70 \%$ of expenditure in 1992 (Boadway et al., 1994, p. 47). In Russia, $60 \%$ of the revenue collected in 1992 was retained by the federal government (Wallich, 1992, p. 33).

The increase in the capacity of subnational spheres to spend was, of course, a result of the increase in fiscal revenues. The financial resources of subnational governments further increased after the 1988 Constitution. Between 1970 and 1985 the federal government remained with an average of $48 \%$ of all public revenue, but the constitution inverted the figures, as shown in Table 2.

Although the constitution changed the distribution of fiscal resources between levels of government, the impact of these changes when compared with GDP was not too significant: the losses of the federal government to the subnational level were less than $1 \%$ of GDP, which meant in estimated terms $8 \%$ of the federal revenue had the previous system been maintained (Afonso, 1994). Resources available to the subnational governments moved from $9 \%$ of GDP in 1980 to $15 \%$ in 1991; their fiscal revenue increased from $6 \%$ of GDP to $9 \%$ in the same period. On the other hand, the federal government's tax revenue declined from 16\% of GDP in 1980 to $14 \%$ in 1991, whereas revenue from the contributions has risen. ${ }^{9}$

One feature of the Brazilian tax system is its constant change. Some examples can be cited. Income tax legislation has been submitted to an average of 15 changes a year since 1988. In 1995, Congress approved a bill proposed by the federal government to increase the rate of corporate income tax, which would raise resources estimated at US\$2 billion in order to alleviate the federal government's cash flow problems. State and municipal taxes approved in 1988 were abolished in 1996. The federal Temporary Tax on Financial Transactions (IPMF) was created in 1993, abolished in 1994 and reintroduced in 1997 with the new acronym of CPMF (Temporary Contribution on Financial Transactions). In 1996 the Provisional Measure No. 1516 increased the contribution on corporate profit of financial institutions in particular. These changes

\footnotetext{
${ }^{9}$ The Brazilian tax system separates taxes and contributions. The main difference is that changes in the levy of taxes should be put into force in the following fiscal year through a constitutional amendment, whereas the rates of contributions can be changed by ordinary law, to take effect 90 days after its promulgation. These resources are earmarked for specific expenditures such as the social security system, unemployment benefit, education, health and welfare programmes and for quangos administered by confederations of corporations. Contributions are not covered by the scheme of revenue sharing with subnational governments, with a few exceptions.
} 
Table 2. Distribution of fiscal revenue in percentage, 1985-1993.

\begin{tabular}{lccccc}
\hline & \multicolumn{2}{c}{$\begin{array}{c}\text { Distribution before the 1988 } \\
\text { Constitution }\end{array}$} & & \multicolumn{2}{c}{$\begin{array}{c}\text { Estimated distribution after the } \\
\text { 1988 Constitution }\end{array}$} \\
\cline { 2 - 3 } \cline { 5 - 6 } Level of government & $\begin{array}{c}\text { (1985) } \\
\text { Share }\end{array}$ & GDP & & $\begin{array}{c}(1993) \\
\text { Share }\end{array}$ & GDP \\
\hline Federal & 44.6 & 6.7 & & 36.5 & 5.7 \\
State & 37.2 & 5.6 & & 40.7 & 6.3 \\
Local & 18.2 & 2.7 & & 22.8 & 3.5 \\
Total & 100.0 & 15.1 & & 100.0 & 15.6 \\
\hline
\end{tabular}

Source. Rezende (1990, p. 161).

go against the requirements of the neoliberal paradigm, which call for stable fiscal rules. All these changes aim at overcoming, albeit temporarily, the federal government's cash flow problems. The constant changes have also transformed the judiciary into an important actor in fiscal issues given the complexity and the ambiguity of the fiscal legislation and its challenges by the taxpayers. ${ }^{10}$

When the constitution was promulgated, the country's economic predicaments were deeper than at the beginning of the decade. The failure of the stabilization plans had been followed by a reduction in public finance, bringing additional constraints to fiscal policy and deficit control. In addition, the proportion of net fiscal resources decreased during the late 1980s when compared with GDP. These trends worsened the distributive cleavages between levels of government, because there were fewer resources to share and to transfer. The decrease in gross revenue from $25 \%$ of GDP between 1970 and 1983 to $20 \%$ in 1989 was not because of a policy for the reduction of tax, but because of inflation, subsidies, tax relief and recession. From 1991, gross revenue increased; however, it has remained stable at around $23 \%$ of GDP until just recently, when it reached $30 \%$, a figure considered too high for developing countries.

The fiscal system has also been affected by the following events: (a) high inflation, at least until the issue of the Real Plan in 1994; (b) tax evasion, estimated at US\$82 billion in 1993 by a CPI (Parliamentary Inquiry Commission) set up by Congress; (c) some years of recession or of slow economic growth; (d) subsidies and tax relief for the middle classes, corporations and regions estimated at 3.2\% of GDP in 1996, amounting to an increase of $196 \%$ when compared with the previous year. The problem with tax relief and subsidies in Brazil rests on the difficulty in withdrawing them once the conditions for which they were set up have changed.

Despite the increase in constitutional transfers to subnational governments, other transfers are also made, taking the format of negotiated grants, also called convenios. The use of negotiated grants to pursue various objectives is a common practice in many countries. They may be destined for less developed areas or for those affected by natural disasters; they may be intended to encourage subnational levels to pursue policies or to implement services which are considered a national priority or which should be provided nationwide; or they may be used to build governing coalitions. In Brazil, negotiated grants are used for all these purposes, including the implementation

\footnotetext{
${ }^{10}$ The ambiguities of tax legislation have led to the judiciary to interpret it against the government. It is estimated that the federal government up to 1993 lost a revenue of US\$3 billion because of judicial decisions. It was reported that, in 1993, 350000 legal actions were on course against the federal treasury challenging the payment of US\$6 billion (Gazeta Mercantil, 9 October 1993).
} 
of the decentralized health programme. However, the debate on the use of negotiated grants reveals that the system has been subject to distortions, such as the transfer of resources to well-developed states. Negotiated transfers were also at the centre of corruption scandals involving Congress and the building industry in 1993, being investigated by a CPI. As a result, several parliamentarians withdrew their seats and a few others were impeached.

The fiscal problem faced by the federal government vis-à-vis the strength of subnational finances does not mean that the federal government is an absent player. ${ }^{11}$ It has been fighting on several fronts to face both its capacity to govern and its cash flow predicament. One of these fronts has been the increase in the rates of taxes and contributions which are not shared with the subnational levels. Pinto (1996), quoting Raul Velloso, argues that COFINS (Contribution for the Financing of the Social Security System) increased by $173 \%$ above inflation between 1992 and 1995 and CSLL (Employers Social Contribution for the Social Security on their Net Profit) by $66 \%$, while income tax increased by only $36 \%$ and IPI (Tax on Industrial Products) by just $4 \%$; the first two (COFINS and CSLL) are not subject to the revenue-sharing scheme with subnational spheres.

\section{THE STRENGTH OF THE STATES IN THE BRAZILIAN FEDERATION}

The states in Brazil have always enjoyed great political power, compared with their financial strength. This power was considered by Brazil's two authoritarian experiences as an obstacle to their objectives: both Vargas and the military regime of 1964 tried to diminish the power of the states by centralizing revenues and by prohibiting popular elections in the states and their capitals. With democratization, however, it was no longer possible to restrain the power of the governors, especially those who govern economically strong states. Furthermore, the influence of the governors upon the state delegation in Congress is now often stronger than that of the political parties to which they belong.

The power of the governors may express itself in several ways, but the main vehicle is the power to veto measures proposed by the federal government which have not previously been negotiated with them. ${ }^{12}$ Negotiations follow three main paths. First, the governors have an important say in the appointment of officials to the federal bureaucracy and to the board of federal-owned companies. Second, the governors negotiate more resources for their states, despite an increase of $3.5 \%$ of the national fiscal revenue granted to them by the 1988 Constitution. These resources are achieved by negotiating larger shares in the federal budget, by the concession of incentives, subsidies and loans at subsidized interest rates, and federal guarantees in loans with international financial organizations. Third, and currently the most important aspect of the federal-state relations, is the governors' strength used as a way to compel the

\footnotetext{
${ }^{11}$ Figueiredo and Limongi are carrying out a research project about Congress, one of the few since the 1988 Constitution. Their research shows evidence of the strength of the federal Executive vis-à-vis the Legislature. See Figueiredo and Limongi (1994) and Limongi and Figueiredo (1996). Following a different direction, Ames (1995) attempts to demonstrate the strength of the regional leaders upon Congress in three different moments of Brazil's recent history.

${ }^{12}$ For more details about the power of the state governors before and after democratization, see Abrucio (1994), Abrucio and Samuels (1997) and Souza (1997a). For a discussion of the role of decentralization in the Brazilian decision-making process, see Kinzo (1996).
} 
federal government to renegotiate the states' debt. In the 1980s and 1990s the states' debt was renegotiated numerous times. The state creditors are mainly the federal government, the commercial banks under the state control, the financial institutions controlled by the federal government and the international financial institutions. This aspect of the relationship between the states and the federal government is one of the most complicated issues and it is also the one which has had the greatest effect on the federal balance and on the performance of the public accounts.

The debt of the states was estimated at around US\$128 billion in December 1996 (Dillinger, 1997), US $\$ 40$ billion in short-term debt, which implies high interest rates. Four states, the most powerful economically, are accountable for $90 \%$ of the debt. Three of these states, São Paulo, Rio de Janeiro and Minas Gerais, are governed by the President's party, the PSBD (Party of Brazilian Social Democracy), and one, Rio Grande do Sul, by the PMDB (Party of the Brazilian Democratic Movement), which belongs to the President's coalition at the national level. Furthermore, these states occupy a high number of seats in Congress, since they are Brazil's most populous states. Large delegations mean that the victory or the failure of measures sent to Congress by the Executive depends, to a great extent, on these delegations. Only three states, Ceará, Bahia and Paraná, the first two situated in the North-East and the latter in the South, are said to have their debts under control. The reasons for their financial adjustment need further investigation; however, they certainly cannot be found on socio-economic grounds, given that Paraná enjoys a better economic position than Ceará and Bahia. An aspect which Ceará and Bahia share is the fact that the same political group has been controlling the state politics since the mid-1980s. As for Paraná, this state has been marked by a tradition of technocratic values, which might mean less room for the politicization of the finance of the state.

Despite the fact that the 1988 Constitution has promoted a great decentralization of the national resources from the federal to the subnational level, solutions have not yet been found to address the problem of the debts inherited by them. This debt constraint has transformed the relationship between the federal government and the states to one in which the negotiation of the states' debts is the only item on the agenda. The Collor administration was the first to have to address the debt problem, and to this day no effective solution has been found.

States and municipalities are today accountable for $51.5 \%$ of the public deficit. The public deficit stands at $31.5 \%$ of GDP. Of the internal federal debt, estimated in June 1996 at $\mathrm{R} \$ 154$ billion, the main item, amounting to $\mathrm{R} \$ 34$ billion, corresponds to the payment of interest following a policy adopted since the issue of the Real Plan designed to restrain consumption and to maintain the stabilization plan. The second item of the internal federal debt, amounting to $\mathrm{R} \$ 29$ billion, corresponds to the federal help given to the states and to the commercial banks under their control.

The relationship between the states and their commercial banks works as follows. As a result of the 1966 fiscal reform, which promoted a centralization of revenues, the state commercial banks were granted permission to make loans to their main shareholders, that is, the states. ${ }^{13}$ Since then the states have been using their commercial banks as one of the main sources of income. The states usually did not pay their debts with their commercial banks and, furthermore, they would request resources the banks did not have, which in turn forced the Central Bank to cover the deficit,

\footnotetext{
${ }^{13}$ For more details about the relationship between the states and their commercial banks, see Souza (1994). 
throwing more currency into the market, thereby pushing up inflation. The states currently owe their commercial banks over $\mathrm{R} \$ 23$ billion, $\mathrm{R} \$ 18$ billion of which corresponds to the state of São Paulo. In December 1996 the debt of São Paulo with its state bank, BANESPA, had increased to US\$21 billion and was the bank's principal 'asset' (Dillinger, 1997).

As a result of this situation, the federal government was put under pressure to withdraw the payment of the states' debts. In August 1996 it finally issued an adjustment programme approved by the CMN (National Monetary Committee). This programme, among other measures, allowed the federal government to back the financial adjustment of the state commercial banks with a view to their privatization. Resources from privatization would be earmarked for the payment of the state's debt with the federal government. However, the state governors appealed against the measure in the Supreme Court and won on the basis that it was unconstitutional. This measure had earlier been approved by the Senate to weaken the position of incumbent governors, who could now remain in office thanks to the constitutional amendment approved in 1997 which allowed for the re-election for executive positions. Furthermore, revenues accruing from the states' share in the federal revenue would be taken as a guarantee for payment. The latter scheme has been unsuccessfully tried in the past. It is estimated that the federal help to the states and their banks will cost the taxpayers R $\$ 50$ billion (Folha de São Paulo, 1 April 1998). Another measure of the renegotiation programme was to determine that the states could only issue new bonds when their debts had become smaller than their annual revenue. As a result, the economically powerful states have to wait until the year 2008 to issue new bonds, with the exception of Minas Gerais which will have to wait until 2014 (Folha de São Paulo, 2 April 1998). It is yet to be seen whether this measure will be enforced.

Paradoxically, Brazilian states are highly capitalized when compared with other federal countries, especially those in the developing world. Furthermore, Brazil is unique in the fact that it has a value-added tax under the jurisdiction of the states. This tax, ICMS (Value-Added, Communication and Transportation Tax), is the highest tax levied in the country, registering increases in its levies higher than inflation rates.

In justifying their web of unpaid debts, the governors blame the high interest rates, which became, according to one of them, Antônio Britto, from Rio Grande do Sul, an unpayable atomic bomb (Folha de São Paulo, 8 August 1996). However, when the policy of high interest rates was not in place, the disarray in the states' finances was much the same as it is today, as shown by Souza (1996b) and Dillinger (1997). This has meant that the indebtedness of the states is more a result of the federal government's need to build governing coalitions, preventing it from adopting tighter controls over the states' debts, together with the federal policy of high interest rates. Therefore the indebtedness of the states is more a result of debts from the past, now aggravated by the policy of high interest rates. Addressing solutions to the state debt clashes with the political strength of the governors, forcing the federal government to postpone the adoption of more definitive solutions, given that the governors are now one of the main partners in the governing coalitions at the national level.

The federal government has shown a willingness to negotiate, yet again, the states' debts. It is also accepting the 'federalization' of part of the states' debts, meaning that their debts with the private banks are transferred to the federal government, although the states should pay for it at subsidized interest rates over 30 years. In exchange the states should privatize state-owned companies, especially those of 
Table 3. State debt renegotiations, as at April 1998.

\begin{tabular}{lcc}
\hline State & $\begin{array}{c}\text { Debt transferred to the } \\
\text { federal government } \\
\text { (R\$ thousand) }\end{array}$ & $\begin{array}{c}\text { Debt re-financed by the } \\
\text { federal government } \\
\text { (R\$ thousand) }\end{array}$ \\
\hline Amazonas & 120000 & 120000 \\
Bahia & 959662 & 906827 \\
Ceará & 114081 & 102916 \\
Espírito Santo & 429887 & 387308 \\
Goiás & 1340356 & 1163057 \\
Maranhão & 244312 & 236502 \\
Minas Gerais & 11827540 & 10185063 \\
Mato Grosso do Sul & 903660 & 806143 \\
Mato Grosso & 805682 & 779943 \\
Pará & 274495 & 261160 \\
Pernambuco & 163641 & 157571 \\
Piauí & 250654 & 240552 \\
Rio Grande do Norte & 57272 & 56479 \\
Rondônia & 146950 & 143677 \\
Roraima & 7247 & 6601 \\
Sergipe & 389065 & 313936 \\
São Paulo & 50388778 & 46585141 \\
\hline
\end{tabular}

Source. Extract from Folha de São Paulo, 1 April 1998.

telecommunications and electricity and state banks, and undergo fiscal adjustment, in particular a reduction in payroll expenditure. ${ }^{14}$ As shown in Table 3, 17 agreements have been made and two, those of São Paulo and Minas Gerais, are of fiscal importance. Two other large debtors, Rio de Janeiro and Rio Grande do Sul, which owned $\mathrm{R} \$ 11,600$ million and $\mathrm{R} \$ 6651$ million respectively, have not yet reached an agreement with the federal government. The same has happened with Alagoas and Acre. The states of Amapá and Tocantins and the Federal District have not joined the programme.

Table 4 shows a different picture, although no less worrying. It depicts the relationship between long-term debt and GDP. According to this indicator, less developed states are in a quite uncomfortable position, despite some improvements in 1994.

Taking the states per se, those that presented the worst performance in 1994 were the states of Piauí (59\%), Paraíba (56\%), Maranhão (55\%), Acre (45\%), Goiás (36\%) and Mato Grosso (35\%). Among the four highest debtors, the position of the state of Minas Gerais is the most critical, with $23 \%$ of its GDP committed to long-term debt, followed by Rio Grande do Sul (19\%), Rio de Janeiro (15\%) and São Paulo (9\%).

Despite the lack of resources available for investment, a calculation by Afonso (1994) demonstrated that, slowly and inconstantly, the states are replacing the federal government in some spheres, while others remain without governmental support because of the backing down of the federal government. This unplanned and uncoordinated transfer of responsibilities contradicts the view that the financial constraints

\footnotetext{
${ }^{14}$ The results of the privatization programme of the state banks have been considered as a failure by the economic team, because 10 states as well as the Federal District have decided to keep control of their banks, as reported by Folha de São Paulo, 2 April 1998. Furthermore, and given the pressures exerted by the governors, the federal government has committed itself to the payment of RS $\$ 1.3$ billion to five states which have decided to keep their commercial banks.
} 
Table 4. Relationship between long-term debt and GDP per region, 1985-1994.

\begin{tabular}{lrrrrrrrrrr}
\hline Region & 1985 & 1986 & 1987 & 1988 & 1989 & 1990 & 1991 & 1992 & 1993 & 1994 \\
\hline North & 4.7 & 3.6 & 7.6 & 9.6 & 12.7 & 4.6 & 11.1 & 15.6 & 20.6 & 12.6 \\
North-East & 17.5 & 11.0 & 20.0 & 32.5 & 32.7 & 24.5 & 25.3 & 33.2 & 47.1 & 23.6 \\
South-East & 5.4 & 3.6 & 6.7 & 12.2 & 14.1 & 10.6 & 12.4 & 19.0 & 24.7 & 12.5 \\
South & 11.2 & 7.9 & 16.9 & 25.7 & 34.2 & 20.0 & 22.5 & 26.0 & 31.0 & 13.6 \\
Centre-West & 19.7 & 11.6 & 23.7 & 38.2 & 38.2 & 25.7 & 27.3 & 34.6 & 45.8 & 25.9 \\
Total & 8.8 & 5.8 & 11.4 & 18.7 & 21.3 & 14.8 & 16.7 & 23.0 & 30.1 & 15.2 \\
\hline
\end{tabular}

Source. IPEA (1977).

faced by the federal government are due solely to the lack of responsibility transfer to the subnational levels. This transfer of responsibilities, however, has not significantly changed policy results at the state level and is subjected to distortions. These distortions are more likely to be explained by the fact that the decision to decentralize was taken without a social consensus on what was to be achieved. Furthermore, intergovernmental relations have become highly politicized since the rules of the fiscal system, including the distribution of revenues between levels of government, are now a detailed chapter of the 1988 Constitution or they are subject to the rule of laws and/or pacts made between the heads of the Executive and Congress.

The federal government has always reacted to the states' pressures in an ambiguous way. The Presidents have tried to promote the idea that the states are responsible for public sector problems, including the public deficit. On the other hand, owing to the increase in the power of the Legislature granted by the Constitution, the Presidents need the state governors' support to obtain congressional approval for their policies because of the influence the governors exert over their state's delegation in Congress. Given that the Presidents always had difficulties guaranteeing a strong and stable parliamentary base, they need to maintain good relations with the governors who can influence the state representation in Congress. In a milieu of political party fragmentation and fragility and of an electoral system of open-list proportional representation, the governors as a group have become one of the main players in assuring the federal government of its capacity to govern. This picture shows that the federal government alone is not in a position to overcome the fiscal constraints of Brazil's public finance.

To sum up, the increase in states' finances gained after the 1988 Constitution has had little effect upon the states themselves because of the size of their inherited debt, aggrandized by the policy of high interest rates, inflation control and the expansion of their payroll expenditure. Despite their financial constraints, the states have increased their influence over the federal government, as well as their veto power, through their political strength and their share in the public deficit. The strength of subnational governments does not mean, however, that Brazil has returned to the ways of the Old Republic, in which the regional interests of a few states prevailed. Between the Old Republic and post-1988 Brazil, the country has become an urban society and an industrial economy, and this has been coupled with improvements in the political and electoral systems, which have become more democratic and competitive.

The power-sharing relationship set up since 1988 does not imply that every state or every municipality enjoys the same amount of power; instead there are several 
unequal but competing power centres which have a voice in deciding on or in vetoing national policies. The existence of several power centres does not mean that the strategies used by the states in the intergovernmental relations are the same. However, the states have created several quasi-institutional, extra-constitutional and extraparliamentary structures and processes in their intergovernmental relations. These structures and processes have assumed various forms. In their relationship with the federal government, structures and processes are developed by the states in the following ways: (a) by the influence governors exert over the states' delegation in Congress; and (b) by appointment to positions in the federal government's governing coalition. To differing degrees the states have increased their bargaining power upon the federal government, strengthening, therefore, the federation.

\section{CONCLUSIONS}

Despite the fact that decentralization strengthens the prospects of democratic consolidation and of federalism by the incorporation of several power centres to the political game, there are political and economic factors which influence the outcomes of decentralization. One of these factors is the limits of financial decentralization in countries where regional and social inequalities are very deep. This point brings an aspect to the discussion of decentralization generally ignored by the literature, that is to say, that decentralization does not occur in a political and economic vacuum but is rather a result of a pre-existent context.

On the other hand, decentralization forces the political system to address solutions to Brazil's regional cleavages, although sometimes only temporarily. Despite the fact that Brazilian federalism has experienced varying features throughout the country's republican history, it has remained a mechanism of political negotiation able to buffer regional inequalities. Since 1988, several competing power centres have had access to the national decision-making process. In a context of a democratic system in which the majority of the political parties are still weak, regional leaders have become a major source of support for the federal government.

The governors' strength does not mean that the federal government is an absent player. The use of federal political appointments, the success in passing bills to temporarily overcome its cash flow problems, the changes already made in sensitive aspects of the constitution and the approval of several stabilization plans prove this argument. At the same time, the governors' strength has created patterns of additional intergovernmental relations, in which extra-constitutional and extra-parliamentary structures and processes are as important as ordinary ones.

Brazil's experience confirms the vision that federalism as a mechanism of territorial power sharing is a way to accommodate conflicts rather than to promote harmony. It also confirms the view developed above that federalism is more an ideology based on values and interests than a commitment based on purely juridical and territorial arrangements. The Brazilian experience also shows that intergovernmental relations are more likely to be based on conflicting interests which are in turn an expression of other political conflicts in society. From this viewpoint one should consider conflicts as inherent to the federal systems and to intergovernmental relations, particularly in countries like Brazil which have opted to make the political 'opening' before fiscal, economic and administrative reforms. In this sense Brazil's experience is, to this day, 
unique. By opting for this path, the federation is strengthened by the incorporation of regional demands to a congested political agenda. However, this path may delay a more definitive solution for Brazil's fiscal and administrative problems, with an impact upon public policies.

\section{REFERENCES}

ABRASF (Associação Brasileira dos Secretários e Dirigentes das Finanças Municipais das Capitais) (1992). Relatório, (several reports).

Abrucio, F. L. (1994). 'Os Barões da federação', Lua Nova, 33, 165-183.

Abrucio, F. and Samuels, D. (1997). 'A nova política dos governadores', Lua Nova, 40/41, $137-166$.

Abrucio, F. L. et al. (1993). 'Decentralização/pacto federativo', Cadernos ENAP, 1(1), 17-33.

Affonso, R. de B. A. and Silva, P. B. L. (1995a). Desigualdades Regionais e Desenvolvimento, FUNDAP/UNESP, São Paulo.

Affonso, R. de B. A. and Silva, P. L. B. (1995b). Reforma Tributária e Federação, FUNDAP/ UNESP, São Paulo.

Affonso, R. de B. A. and Silva, P. L. B. (1995c). A Federação em Perspectiva, FUNDAP/ UNESP, São Paulo.

Affonso, R. de B. A. and Silva, P. L. B. (1996a). Empresas Estatais e Federação, FUNDAP/ UNESP, São Paulo.

Affonso, R. de B. A. and Silva, P. L. B. (1996b). Descentralização e Politicas Sociais, FUNDAP/UNESP, São Paulo.

Afonso, J. R. (1994). Descentralização Fiscal na América Latina: Estudo de Caso do Brasil, Naciones Unidas/Comision Economica Para America Latina y el Caribe, Santiago.

Afonso, J. R. and Lobo, T. (1996). 'Descentralização fiscal e participação em experiências democráticas retardatárias', paper presented at the Tinker Forum on the Role of the State in Latin America and Caribbean, Cancún

Albuquerque, R. C. (1993). 'Development disparities and social strategies for the 1990s', paper presented at the conference Brazil: the Struggle for Modernization, London.

Ames, B. (1996). 'Electoral rules, constituency pressures, and pork barrel: bases of voting in the Brazilian Congress', Journal of Politics, 57, 324-343.

Boadway, R., Roberts, S. and Shah, A. (1994). 'The reform of fiscal systems in developing and emerging market economies: a federalism perspective', World Bank Policy Research Working Paper 1259, Washington, DC.

Burgess, M. (1993a). 'Federalism and federation: a reappraisal', in Burgess, M. and Gagnon, A.-G. (eds), Comparative Federalism and Federation: Competing Traditions and Future Development, Harvester Wheatsheaf, New York, 3-13.

Burgess, M. (1993b). 'Federalism as political ideology: interests, benefits and beneficiaries in federalism and federation', in Burgess, M. and Gagnon, A.-G. (eds), Comparative Federalism and Federation: Competing Traditions and Future Developments, Harvester Wheatsheaf, New York, 102-113.

Camargo, A. (1993). 'Poor cousin, rich cousin', Braudel Papers, 4(3), p. 2, September.

CEI (Centro de Estatística e Informações) (1992). Produto Interno Bruto-Bahia 1975/1991, CEI, Salvador.

Dillinger, W. (1997). Brazil's State Debt Crisis: Lessons Learned, World Bank, Washington, DC.

Duchacek, I. D. (1987). Comparative Federalism, University Press of America, Lanham.

Elazar, D. J. (1984). Self-rule/Shared Rule: Federal Solutions to the Middle East Conflict, University Press of America, Lanham.

Else-Mitchell, R. (1983). 'Unity or uniformity?', in Aldred, J. and Wilkes, J. (eds), A Fractured Federation? Australia in the 1980s, George Allen and Unwin, Sydney, 1-18.

Figueiredo, A. and Limongi, F. (1994). 'O processo legislativo e a produção legal no Congresso pós-Constituinte', Novos Estudos CEBRAP, 38, 30-42. 
Fiori, J. L. (1995). 'O federalismo diante do desafio da globalização', in Affonso, R. de B. A. and Silva, P. L. B. (eds), A Federação em Perspectiva: Ensaios Selecionados, FUNDAP, São Paulo, 19-38.

Gagnon, A.-G. (1993). 'The political uses of federalism', in Burgess, M. and Gagnon, A.-G. (eds), Comparative Federalism and Federation: Competing Traditions and Future Developments, Harvester Wheatsheaf, New York, 000-000.

Guimarães Neto, L. (1995). 'Dinâmica recente das economias regionais brasileiras', São Paulo em Perspectiva, 9(3), 24-37.

Harman, G. (1992). 'Intergovernmental relations: federal systems', in Hawkesworth, M. and Kogan, M. (eds), Encyclopedia of Government and Politics, Routledge, London, $336-350$

IPEA (Instituo de Pesquisa Econômica Aplicada) (1993). O Mapa da Fome: Subsidios à Formulação de uma Politica de Sergurança Alimentar, IPEA, Brasilia.

IPEA (Instituo de Pesquisa Econômica Aplicada) and IBAM (Instituto Brasileiro de Administração Municipal) (1994). O Novo Pacto Federativo, IBAM, Rio de Janeiro.

IPEA (Instituo de Pesquisa Econômica Aplicada) and PNUD (Programa das Nações Unidas para o Desenvolvimento) (1996). Relatório Sobre o Desenvolvimento Humano no Brasil, Rio de Janeiro PNUD, Brasília.

IPEA (Instituto de Pesquisa Econômica Aplicada) (1997). Atlas Regional da Desigualdade, IPEA/DIPES, Brasília.

Kinzo, M. D’A. G. (1996). 'Governabilidade, estrutura institucional de processo decisório no Brasil', paper presented at the Seminário para a Elaboração de uma Agenda Nacional de Governabilidade, Brasília.

Levin, J. (1991). 'Measuring the role of subnational governments', IMF Working Paper 91/8, Washington, DC.

Lijphart, A. (1984). Democracies: Patterns of Majoritariam and Consensus Government in Twenty-one Countries, Yale University Press, New Haven, CT.

Limongi, F. and Figueiredo, A. (1996). 'Presidencialismo e apoio partidário no Congresso', Monitor Público, 8(3), 27-35.

Melo, M. A. (1996). 'Crise federativa, guerra fiscal e "hobbesianismo municipal": efeitos perversos da descentralização?', São Paulo em Perspectiva, 10(3), 11-20.

Pinto, C. (1996). 'A rebelião dos estados', Folha de São Paulo, 11 October.

Rezende, F. (1990). 'Descentralização e eficiência: a tomada de decisões para o desenvolvimento sob a Constituição de 1988', in Programa das Nações Unidas para o Desenvolvimento (ed.), Politicas de Desenvolvimento para a Década de Noventa, PNUD, Brasília, $141-167$

Rydon, J. (1993). 'The Australian tradition of federalism and federation', in Burgess, M. and Gagnon, A.-G. (eds), Comparative Federalism and Federation: Competing Traditions and Future Developments, Harvester Wheatsheaf, New York, 227-241.

Shah, A. (1991). 'The new fiscal federalism in Brazil', World Bank Discussion Paper 124, Washington, DC.

Shapira, M. F. P. (1992). 'Argentine: féderalisme et territoires', Cahiers des Amériques Latines, 14, 5-33.

Sontheimer, K. (1988). 'The Federal Republic of Germany (1949): restoring the Rechtsstaat', in Bogdanor, V. (ed.), Constitutions in Democratic Politics, Gower, Aldershot.

Souza, C. (1992). 'Democracia, participação social e funcionamento das instituições: situação e perspectivas da federalização do desenvolvimento', Revista de Administração Pública, 26(3), 15-35.

Souza, C. (1994). 'Political and financial decentralisation in democratic Brazil', Local Government Studies, 20(4), 588-609.

Souza, C. (1996a). 'Reinventando o poder local: limites e possibilidades do federalismo e da descentralização', São Paulo em Perspectiva, 10(3), 38-52.

Souza, C. (1996b). 'Redemocratization and decentralization in Brazil: the strength of the member states', Development and Change, 27(3), 529-555.

Souza, C. (1997a). Constitutional Engineering in Brazil: the Politics of Federalism and Decentralization, Macmillan/St Martin' Press, London/New York. 
Souza, C. (1997b). 'Regional interest intermediation in Brazil: the impact of federalism and decentralisation', in Kinzo, M. D'A. G. (ed.), Reforming the State: Business, Unions and Regions in Brazil, Institute of Latin American Studies, London, 36-53.

Souza, C. (1997c). 'Federalismo, descentralização e reforma constitucional em contextos de desenvolvimento regional desigual', Organizações \& Sociedade, 4(9), 127-148.

Stewart, W. (1984). Concepts of Federalism, University Press of America, Lanham.

Wallich, C. (1992). 'Fiscal decentralization: intergovernmental relations in Russia', World Bank Studies of Economies in Transformation Paper 6, Washington, DC. 